\title{
Cobalt Phthalocyanine-Sensitized Graphene-ZnO Composite: An Efficient Near-Infrared-Active Photothermal Agent
}

\author{
Gururaj M. Neelgund ${ }^{\odot}$ and Aderemi Oki* \\ Department of Chemistry, Prairie View A\&M University, Prairie View, Texas 77446, United States \\ Supporting Information
}

\begin{abstract}
Herein, a promising near-infrared-responsive photothermal agent was designed by anchoring of rice grainshaped $\mathrm{ZnO}$ particles over graphene (GR) nanosheets and subsequent sensitization with cobalt phthalocyanine $(\mathrm{CoPc})$. Thus, produced GR- $\mathrm{ZnO}-\mathrm{CoPc}$ was able to attain the temperature of $68{ }^{\circ} \mathrm{C}$ by irradiating to $980 \mathrm{~nm}$ laser for 7 min, which is extremely higher than the endurance temperature of cancer cells. The linear fashioned progression in the photothermal effect of GR nanosheets was conquered by immobilization of $\mathrm{ZnO}$ particles and successive sensitization with CoPc. The excellence found in the photothermal effect of $\mathrm{GR}-\mathrm{ZnO}-\mathrm{CoPc}$ was verified by estimation of its photothermal conversion efficiency. The photothermal conversion efficiency assessed for $\mathrm{GR}-\mathrm{ZnO}-\mathrm{CoPc}$ was higher than those for the popular gold- and CuS-based photothermal agents. In addition, it possessed significant stability against photobleaching and structural rupture. It was found that the photothermal effect of $\mathrm{GR}-\mathrm{ZnO}-\mathrm{CoPc}$ is proportional to its concentration. However, by replacement of a $980 \mathrm{~nm}$ laser system with $808 \mathrm{~nm}$, the photothermal effect of $\mathrm{GR}-\mathrm{ZnO}-\mathrm{CoPc}$ was reduced, which could be due to lower absorption of GR- $\mathrm{ZnO}-\mathrm{CoPc}$ at $808 \mathrm{~nm}$ compared to $980 \mathrm{~nm}$. On account of its significance and important properties, $\mathrm{GR}-\mathrm{ZnO}-\mathrm{CoPc}$ could be an interesting photothermal agent to employ in future photothermal therapy for cancer.
\end{abstract}

\section{INTRODUCTION}

Cancer is a current major cause for morbidity and mortality in humans. The main feature of cancer tissues is the decreased level of oxygen called hypoxia, and it leads to proliferation, angiogenesis, and metastasis of cancer cells. ${ }^{1}$ For cancer therapy, different therapeutic modalities have been employed, in which the mainstream approaches are surgery, chemotherapy, and radiotherapy. ${ }^{2}$ However, these therapies are associated with a number of disadvantages, such as damaging of healthy tissues, attacking of immune system, invasive, toxic side effects, poor tumor-selectivity, and limited efficacy. ${ }^{2}$ Therefore, advanced therapies having high efficiency and precision are critically needed for cancer. One of the promising therapies is hyperthermia in which cancer cells are selectively targeted and destroyed by exposing to near-infrared (NIR)mediated high temperature. Hyperthermia can destroy cancer cells in a selective manner, and a gifted approach for hyperthermia to deliver NIR-facilitated thermal energy to ablate cancer cells is photothermal therapy (PTT). PTT is an innovative method in cancer therapy, and it relies on conversion efficiency of photon energy into heat through a photosensitizer called a photothermal agent under illumination of NIR light. Irradiation of a photothermal agent injected in cancer cells by NIR laser leads to rapid rise in the local cellular temperature above the threshold value beyond $50{ }^{\circ} \mathrm{C}$ for $4-6$ min of period or over $42-45{ }^{\circ} \mathrm{C}$ (a mild hyperthermia condition) with 15-60 min to cause denaturation of protein, disruption of the cellular membrane, and ablation of cancer cells. ${ }^{3}$ In other words, PTT is a distinct phototherapy that results in damaging of cancer cells owing to heat generated by the photosensitizer by absorption of NIR light radiations. ${ }^{2}$ So that, the photosensitizer is the key factor to succeed in PTT. Recently, a range of nanomaterials have been discovered and explored as photosensitizers for PTT. $^{3}$ Among various photothermal agents, graphene (GR) holds critical importance due to its distinctive physical and chemical properties. ${ }^{4,5} \mathrm{GR}$ possess two-dimensional (2D) one-atom-thickness with a honeycomb structure of $\mathrm{sp}^{2}$-hybridized carbon atoms. ${ }^{4}$ In addition, GR consists of elevated electron transport aptitude at room temperature, excellent elasticity and thermal conductivity, high mechanical strength, tunable optical properties, quantum Hall effect at room temperature, high effective surface area, and tunable band gap. ${ }^{4}$ Since its revolutionary discovery in 2004 by Geim and Novoselov, ${ }^{6}$ GR is massively explored in the areas of catalysis, sensing, energy, and electrical and electronics applications. ${ }^{7-10}$ However, it has been least probed in the biomedical area despite its excellent biocompatibility. In particular, potential use of GR in PTT is still under

Received: November 19, 2018

Accepted: March 5, 2019

Published: March 21, 2019 
nascent stage and limited. GR introduced in cancer cells can derive its vibrational modes into thermal energy after irradiating to NIR radiations, cause a rise in temperature around the cancerous tissue, and structurally change their cellular and protein configurations, and cause the ablation., ${ }^{2,4}$ Therefore, it is currently critically needed to evaluate the possibilities of GR in PTT.

Another important material that has equal importance like GR is $\mathrm{ZnO} .^{11} \mathrm{ZnO}$ is an important n-type semiconductor and has a direct wide band gap of $3.37 \mathrm{eV}$ and strong exciton binding energy of $60 \mathrm{meV} .^{12,13}$ Moreover, $\mathrm{ZnO}$ exhibits excellent optical activity, good stability, and high electron mobility of $200-300 \mathrm{~cm}^{2} \mathrm{~V}^{-1} \mathrm{~s}^{-1} \cdot{ }^{12,14} \mathrm{ZnO}$ is inherently nonhazardous to mammalian cells owing to its chemical inertness and stability under physiological conditions. However, $\mathrm{ZnO}$ can cause cytotoxic effects in cancer cells and destroy them. ${ }^{11}$ Hence, $\mathrm{ZnO}$ could be a promising candidate for the next-generation biomedical applications, and it has been broadly executed as a nanocarrier for various biomolecules. $^{15,16}$ However, UV emission connected with excitonic band edge and visible emission attributed with sundry intrinsic defects of $\mathrm{ZnO}$ has restricted its use merely to $\mathrm{UV}$ and visible radiations. ${ }^{17}$ Hence, to modify the response of $\mathrm{ZnO}$ toward NIR radiations, it is crucial to conjugate it with a secondary candidate such as GR. Owing to the distinct properties of $\mathrm{GR}$, its combination with $\mathrm{ZnO}$ can prolong the ability of $\mathrm{ZnO}$ to absorb NIR radiations. With this emphasis, herein, $\mathrm{ZnO}$ was blended with GR and succeeded in extending the absorption of $\mathrm{ZnO}$ toward the NIR region. ${ }^{12,14}$ So far, application of $\mathrm{ZnO}$ in PTT is still at a budding stage, so, execution of possible employment of $\mathrm{ZnO}$ in PTT is absolutely needed.

Phthalocyanines (Pcs) are an important class of organic semiconductors as they behave as photosensitizers. ${ }^{18-22}$ Pcs are known as second-generation photosensitizers, having exceptional photostability and act as p-type semiconductors. ${ }^{23}$ Pcs hold extended absorption wavelengths $\left(\lambda_{\max }>660 \mathrm{~nm}\right)$, high extinction coefficients $\left(\varepsilon_{\max }>10^{5} \mathrm{~L} \mathrm{~mol}^{-1} \mathrm{~cm}^{-1}\right)$, exceptional thermal stability, and variable photophysical and photochemical properties. ${ }^{21}$ Furthermore, the absorption of Pcs in the NIR region is particularly important as it takes the benefit of spectral concurrence with the tissue-transparent window, where minimal photon interferences (absorption, autofluorescence, and scattering) from solvents, biomolecules, and the biological matrix allow for deeper light penetration and minimum invasiveness. ${ }^{24}$ Moreover, Pcs exhibit low dark toxicity and strong phototoxicity because of their capability to produce cytotoxic reactive oxygen species, specially singlet oxygen. $^{24}$ Owing to their aptitude in generation of singlet oxygen $\left({ }^{1} \mathrm{O}_{2}\right)$ by irradiating to light, Pcs are approved by US Food and Drug Administration for clinical applications in cancer therapy. ${ }^{18}$ However, Pcs have been least employed in PTT owing to their hydrophobic nature that causes poor selectivity, solubility, and transportation of Pcs into cancer cells. Thus, to overcome this major defect of Pcs, their integration with other innovative materials such as $\mathrm{ZnO}$ and GR might be the right approach. Therefore, in consideration of their unique benefits, herein, we successfully merged $\mathrm{GR}, \mathrm{ZnO}$, and cobalt phthalocyanine $(\mathrm{CoPc})$ by deposition of rice grainshaped $\mathrm{ZnO}$ microparticles over GR nanosheets and subsequent sensitization with CoPc. Thus prepared GR$\mathrm{ZnO}-\mathrm{CoPc}$ has demonstrated significant photothermal effect (PTE) required for PTT of cancer. Overall, a methodical augmentation in the PTE of GR was achieved by deposition of $\mathrm{ZnO}$ particles on its surfaces and successively sensitizing with CoPc.

\section{RESULTS AND DISCUSSION}

The X-ray diffraction (XRD) of GR- $\mathrm{ZnO}$ (Figure 1a) depicted the characteristic reflection of GR nanosheets at $2 \theta$

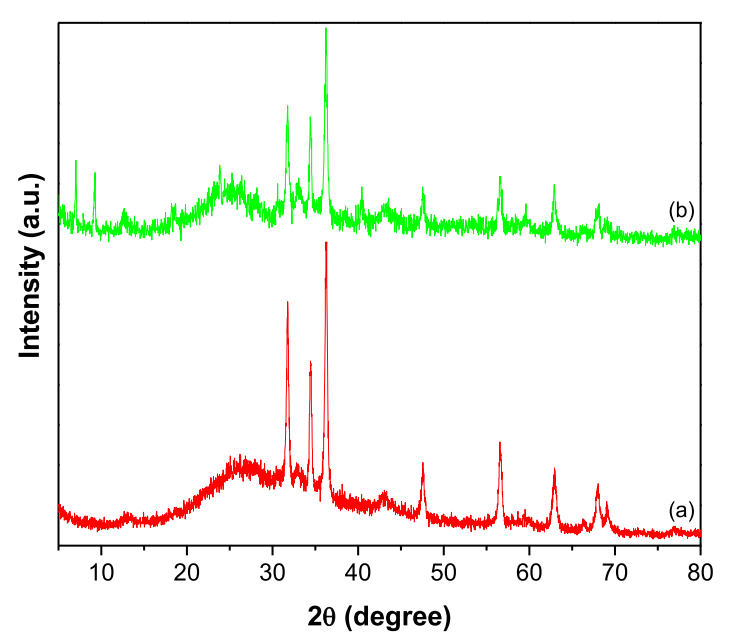

Figure 1. $\mathrm{XRD}$ pattern of (a) GR- $\mathrm{ZnO}$ and (b) GR- $\mathrm{ZnO}-\mathrm{CoPc}$.

value of $26.2^{\circ}$ corresponding to $\left(\begin{array}{lll}0 & 0 & 2\end{array}\right)$. In addition, it displayed the reflections of $\mathrm{ZnO}$ at $31.78^{\circ}, 34.4^{\circ}, 36.2^{\circ}, 47.6^{\circ}$, $56.6^{\circ}, 62.9^{\circ}, 68.0^{\circ}$, and $69.0^{\circ}$ owing to (lll $\left.\begin{array}{lll}1 & 0 & 0\end{array}\right),\left(\begin{array}{lll}0 & 0 & 2\end{array}\right),\left(\begin{array}{ll}1 & 0\end{array}\right.$ 1), ( $\left.\begin{array}{lll}1 & 0 & 2\end{array}\right),\left(\begin{array}{lll}1 & 1 & 0\end{array}\right),\left(\begin{array}{lll}1 & 0 & 3\end{array}\right),\left(\begin{array}{lll}1 & 1 & 2\end{array}\right)$, and ( $\left(\begin{array}{lll}2 & 0 & 1\end{array}\right)$ reflection planes of $\mathrm{ZnO}$ (JCPDS file no. 36-1451). The pattern of GR$\mathrm{ZnO}-\mathrm{CoPc}$ (Figure 1b) illustrated the diffraction peaks ascribed to both $\mathrm{GR}$ and $\mathrm{ZnO}$, in addition to peaks corresponding to $\mathrm{CoPc}$ at $7.0^{\circ}, 9.3^{\circ}, 23.8^{\circ}, 33.1^{\circ}$, and $40.4^{\circ}$ (JCPDS file no. 44-1994). It reveals the successful preparation of $\mathrm{GR}-\mathrm{ZnO}$ and its sensitization with CoPC. To further characterize, attenuated total reflection (ATR)-IR spectra were employed. The spectrum of GR- $\mathrm{ZnO}$ (Figure 2a) displayed a band at $1491 \mathrm{~cm}^{-1}$ due to the skeletal vibration of GR and additional broad absorption band at $3195 \mathrm{~cm}^{-1}$ by stretching vibrations of hydroxyl groups of water molecules

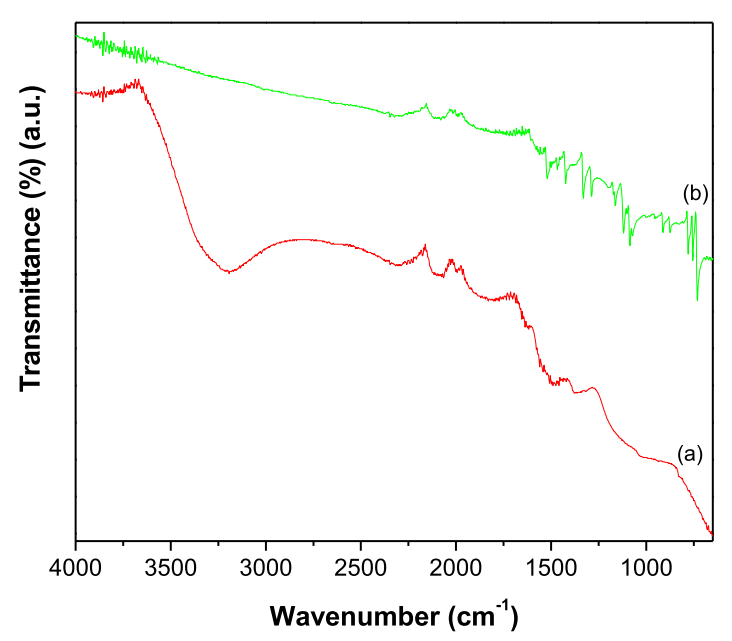

Figure 2. ATR-IR spectra of (a) GR- $\mathrm{ZnO}$ and (b) GR- $\mathrm{ZnO}-$ CoPc. 
absorbed over the surface of GR- $\mathrm{ZnO}$. However, the spectrum of $\mathrm{GR}-\mathrm{ZnO}-\mathrm{CoPc}$ (Figure $2 \mathrm{~b}$ ) demonstrated the essential characteristic peaks of the Pc moiety, in which, the bands at 730,754 , and $779 \mathrm{~cm}^{-1}$ were consigned to aromatic ring of benzene. In particular, the band at $730 \mathrm{~cm}^{-1}$ is owing to nonplanar deformation vibrations of $\mathrm{C}-\mathrm{H}$ bonds, whereas the bands found at 754 and $779 \mathrm{~cm}^{-1}$ were due to nonplanar vibrations (out-of-plane bending) of $\mathrm{C}-\mathrm{H}$ bonds of the benzene ring. The metal to ligand $(\mathrm{M}-\mathrm{N})$ vibration of $\mathrm{CoPc}$ was perceived at $911 \mathrm{~cm}^{-1}$. The absorptions present at 1086 and $1118 \mathrm{~cm}^{-1}$ were due to $\mathrm{C}-\mathrm{N}$ stretching and $\mathrm{C}-\mathrm{H}$ in-plane bending vibrations, respectively, of $\mathrm{CoPc} .^{25}$ The pyrrole $\mathrm{C}-\mathrm{C}$ stretching tied-up with aza rocking was displayed at $1331 \mathrm{~cm}^{-1}$, and $\mathrm{C}-\mathrm{H}$ deformation was observed at $1288 \mathrm{~cm}^{-1} .^{26}$ The band at $1424 \mathrm{~cm}^{-1}$ was due to $\mathrm{C}-\mathrm{C}$ benzene ring skeletal stretching vibrations, and the band at $1521 \mathrm{~cm}^{-1}$ was due to stretching of the pyrrole ring. ${ }^{26}$

The surface morphology accessed by field emission scanning electron microscopy (FESEM) provided the distinct visibility of the presence of GR nanosheets and $\mathrm{ZnO}$ particles in GR$\mathrm{ZnO}$ (Figure 3a,b). The rice grain-shaped $\mathrm{ZnO}$ microparticles
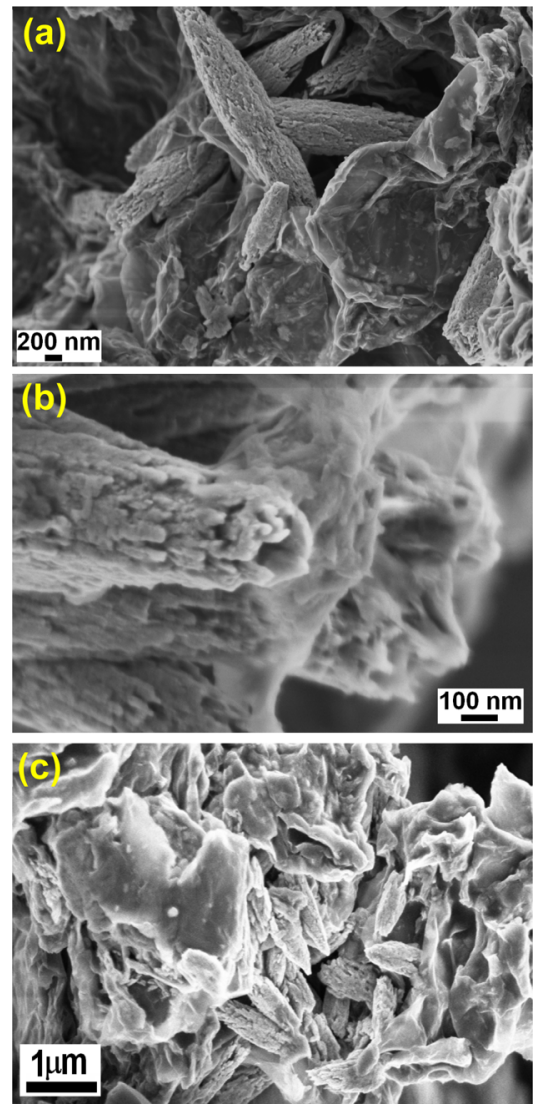

Figure 3. SEM images of (a,b) GR- $\mathrm{ZnO}$ and (c) GR- $\mathrm{ZnO}-\mathrm{CoPc}$.

are strongly adhered over the corrugated and scrolled GR nanosheets. The intimate interaction between GR nanosheets and elongated $\mathrm{ZnO}$ particles is obviously identifiable in Figure $3 \mathrm{a}, \mathrm{b}$, and it facilitates rapid transfer of photo-generated charge carriers to improve the photosensitive activity of $\mathrm{GR}-\mathrm{ZnO}$. In $\mathrm{GR}-\mathrm{ZnO}, \mathrm{ZnO}$ particles are randomly oriented over the smooth and wrinkled surfaces of GR nanosheets. The $\mathrm{ZnO}$ particles have hollow interior of about $100 \mathrm{~nm}$ diameter and irregular surface morphology (Figure 3b). Nonetheless, the surface morphology of GR- $\mathrm{ZnO}$ was not influenced by sensitizing it with $\mathrm{CoPc}$ (Figure 3c). Hence, the surface morphology of $\mathrm{GR}-\mathrm{ZnO}$ is identical in $\mathrm{GR}-\mathrm{ZnO}-\mathrm{CoPc}$ also (Figure 3c). The existence of densely populated $\mathrm{ZnO}$ particles on the surface of GR nanosheets is perceptible in GR- $\mathrm{ZnO}-$ CoPc. However, existence of $\mathrm{CoPc}$ is unidentifiable in GR$\mathrm{ZnO}-\mathrm{CoPc}$, which could be due to low concentration of CoPc. To identify sensitization of GR- $\mathrm{ZnO}$ with $\mathrm{CoPc}$ in detail, energy-dispersive X-ray spectroscopy (EDS) was implemented. The EDS of GR-ZnO (Figure S1) indicated the occurrence of $\mathrm{C}, \mathrm{Zn}, \mathrm{O}$, and $\mathrm{Cu}$. Among these, $\mathrm{C}$ is originated by $\mathrm{GR}$ nanosheets, and $\mathrm{Zn}$ and $\mathrm{O}$ are owing to $\mathrm{ZnO}$ particles. In addition, $\mathrm{GR}-\mathrm{ZnO}$ exhibited the presence of $\mathrm{Cu}$ because of the copper sample holder used in the EDS measurement. The EDS of $\mathrm{GR}-\mathrm{ZnO}-\mathrm{CoPc}$ (Figure S2) demonstrated the peak corresponding to $\mathrm{Co}$ apart from $\mathrm{C}, \mathrm{Zn}$, and $\mathrm{O}$. To further authenticate the sensitization of $\mathrm{GR}-\mathrm{ZnO}$ with $\mathrm{CoPc}$, elemental mapping was carried out. The element mapping images of GR- $\mathrm{ZnO}-\mathrm{CoPc}$, shown in Figure $4 \mathrm{a}-\mathrm{d}$
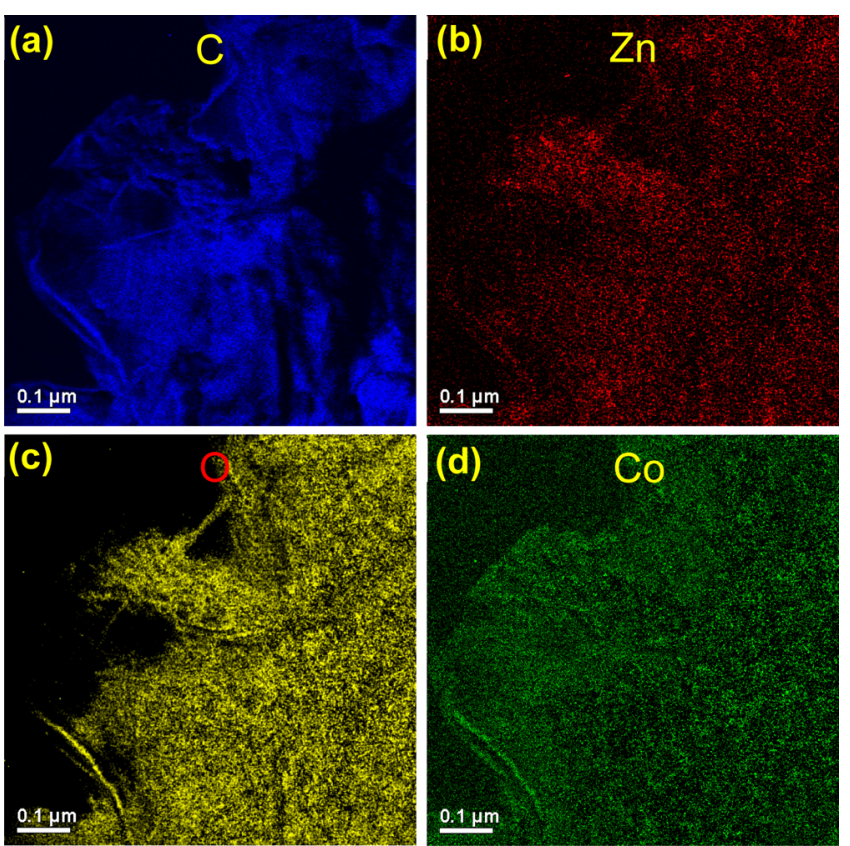

Figure 4. Element mapping images of $\mathrm{GR}-\mathrm{ZnO}-\mathrm{CoPc}$.

verify the content of $\mathrm{C}, \mathrm{Zn}, \mathrm{O}$, and $\mathrm{Co}$ and their uniform distribution all over the sample. The dispersal of $\mathrm{O}$ corresponds well with elemental $\mathrm{Zn}$, and it is in accordance with elemental $\mathrm{C}$ and Co mapping. The element mapping reveals uniform distribution of $\mathrm{ZnO}$ and $\mathrm{CoPc}$ on the GR nanosheets, and the element mapping of $\mathrm{GR}-\mathrm{ZnO}-\mathrm{CoPc}$ is in compliance with its EDS.

The surface morphology of $\mathrm{GR}-\mathrm{ZnO}$ and $\mathrm{GR}-\mathrm{ZnO}-\mathrm{CoPc}$ was further examined by transmission electron microscopy (TEM), and the obtained images are depicted in Figure 5a,b, respectively. The manifestation of GR nanosheets and $\mathrm{ZnO}$ particles are noticeable in the image of GR- $\mathrm{ZnO}$ (Figure 5a). The scrambled nature of GR nanosheets and their close contact and strong interaction with $\mathrm{ZnO}$ particles is observable in $\mathrm{GR}-\mathrm{ZnO}$. The $\mathrm{ZnO}$ particles possess zigzag fashioned edges and a nonuniform surface, whereas the GR nanosheets have a uniform and smooth surface. The $2 \mathrm{D}$ nature of GR nanosheets is apparent in the image of $\mathrm{GR}-\mathrm{ZnO}-\mathrm{CoPc}$ 


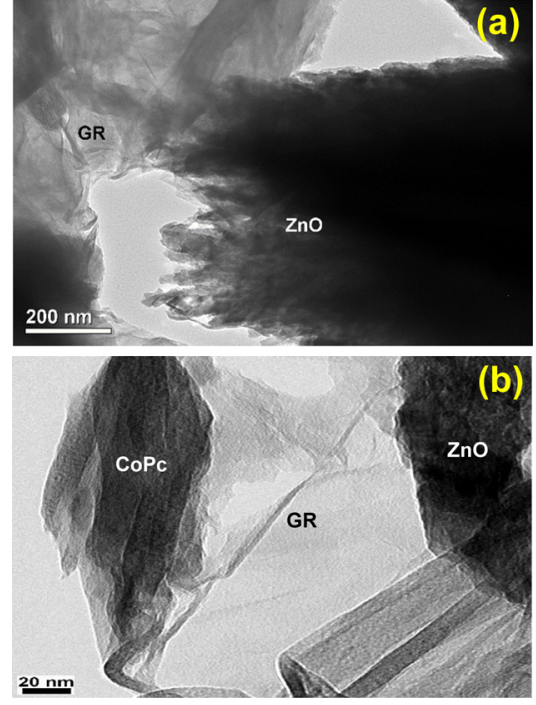

Figure 5. TEM images of (a) GR- $\mathrm{ZnO}$ and (b) GR- $\mathrm{ZnO}-\mathrm{CoPc}$.

(Figure 5b) as these sheets have several microns of length and width, and about 7-8 nm of thickness. Owing to their nanometer thickness, the GR nanosheets appear like a silky wave having absolute transparency. The $\mathrm{ZnO}$ particles are immobilized over the GR nanosheet, and the incidence of $\mathrm{CoPc}$ is visible in $\mathrm{GR}-\mathrm{ZnO}-\mathrm{CoPc}$. In Figure $5 \mathrm{~b}$, existence of a single GR nanosheet is distinctly visible, and it demonstrates that the deposition of $\mathrm{ZnO}$ particles and sensitization with $\mathrm{CoPc}$ has successfully prohibited the bundling of GR nanosheets in $\mathrm{GR}-\mathrm{ZnO}-\mathrm{CoPc}$.

The X-ray photoelectron spectra (XPS) scrutinized the chemical composition and potential structure of $\mathrm{GR}-\mathrm{ZnO}$ and $\mathrm{GR}-\mathrm{ZnO}-\mathrm{CoPc}$ (Figure 6). The survey spectra of GR- $\mathrm{ZnO}$ and $\mathrm{GR}-\mathrm{ZnO}-\mathrm{CoPc}$ presented in Figure 6a exhibited the characteristics peaks corresponding to $\mathrm{C}, \mathrm{Zn}$, and $\mathrm{O}$. These elements have been precisely accessed through their high resolution spectra. The spectrum of $\mathrm{C} 1 \mathrm{~s}$ (Figure $6 \mathrm{~b}$ ) provided the characteristic peak at 287.2 and $287.1 \mathrm{eV}$ for GR- $\mathrm{ZnO}$ and $\mathrm{GR}-\mathrm{ZnO}-\mathrm{CoPc}$, respectively. This peak of $\mathrm{C} 1 \mathrm{~s}$ is assigned to $\mathrm{C}-\mathrm{C}$ and $\mathrm{C}=\mathrm{O}$ bonds of the GR nanosheets. ${ }^{27}$ However, the spectrum of $\mathrm{Zn} 2 \mathrm{p}$ (Figure $6 \mathrm{c}$ ) was fragmented into two distinctive energy levels, viz., $\mathrm{Zn} 2 \mathrm{p}_{3 / 2}$ and $\mathrm{Zn} 2 \mathrm{p}_{1 / 2}$ situated at 1025.2 and $1048.0 \mathrm{eV}$, respectively, in $\mathrm{GR}-\mathrm{ZnO}$, and at 1024.8 and $1048.0 \mathrm{eV}$, respectively, in $\mathrm{GR}-\mathrm{ZnO}-\mathrm{CoPc}$. The energy value corresponding to the spin-orbital coupling was estimated for the fragmentation of $\mathrm{Zn} 2 \mathrm{p}_{3 / 2}$ and $\mathrm{Zn} 2 \mathrm{p}_{1 / 2}$ peaks, and it was found to be 22.8 and $23.2 \mathrm{eV}$ for $\mathrm{GR}-\mathrm{ZnO}$ and $\mathrm{GR}-\mathrm{ZnO}-\mathrm{CoPc}$, respectively. ${ }^{28}$ It represents the presence of $\mathrm{Zn}$ atoms with their oxidation state of +2 in $\mathrm{GR}-\mathrm{ZnO}$ and $\mathrm{GR}-\mathrm{ZnO}-\mathrm{CoPc}$. In particular, the peak displayed around $1025 \mathrm{eV}$ is accompanied with $\mathrm{Zn}^{2+}$ present in wurtzite-structured $\mathrm{ZnO}$. The spectrum of $\mathrm{O} 1 \mathrm{~s}$ region (Figure 6d) depicts the peak with the binding energy of 534.8 $\mathrm{eV}$ in both $\mathrm{GR}-\mathrm{ZnO}$ and $\mathrm{GR}-\mathrm{ZnO}-\mathrm{CoPc}$ by oxygen ions of $\mathrm{ZnO}{ }^{29}$ Accordingly, the intense peaks found for $\mathrm{Zn} 2 \mathrm{p}$ and $\mathrm{O}$ 1s regions in Figure 6a reveal the occurrence of $\mathrm{Zn}^{2+}$ and $\mathrm{O}^{2-}$ in the formation of bonds between the $\mathrm{Zn}$ and $\mathrm{O}$ ions of $\mathrm{ZnO}$ present in $\mathrm{GR}-\mathrm{ZnO}$ and $\mathrm{GR}-\mathrm{ZnO}-\mathrm{CoPc}$. The presence of the peak corresponding to Co $2 \mathrm{p}$ around $780 \mathrm{eV}$ is barely detectable in the spectrum of $\mathrm{GR}-\mathrm{ZnO}-\mathrm{CoPc}$, which could be owing to low concentration of $\mathrm{CoPc}$ in the sample. However, GR- $\mathrm{ZnO}-\mathrm{CoPc}$ displayed the peak of $\mathrm{N}$ 1s at
$401.2 \mathrm{eV}$ (Figure 6e), which originates from the Pc moiety of $\mathrm{CoPc}$ present in GR-ZnO-CoPc. Compared to GR-ZnO, position of the peaks was not significantly varied in GR$\mathrm{ZnO}-\mathrm{CoPc}$; it suggests that sensitization of $\mathrm{GR}-\mathrm{ZnO}$ with $\mathrm{CoPc}$ did not modify the inherent structure of GR-ZnO.

The NIR response of GR- $\mathrm{ZnO}$ and $\mathrm{GR}-\mathrm{ZnO}-\mathrm{CoPc}$ was preliminarily estimated using UV-vis-NIR spectra (Figure 7). The spectrum of GR- $\mathrm{ZnO}$ (Figure $7 \mathrm{a}$ ) provided an electronic absorption band at $270 \mathrm{~nm}$, corresponding to $\pi \rightarrow \pi^{*}$ transitions of aromatic $\mathrm{C}-\mathrm{C}$ bonds present in the GR nanosheets. ${ }^{25}$ Additional, important absorption was revealed at $375 \mathrm{~nm}$, which is consistent with the characteristic absorption of $\mathrm{ZnO}{ }^{12,25}$ Therefore, the spectrum of GR$\mathrm{ZnO}$ advises the presence of GR and $\mathrm{ZnO}$. Furthermore, it disclosed the band between 930 and $1050 \mathrm{~nm}$ and validated its higher absorption of aqueous dispersion of $\mathrm{GR}-\mathrm{ZnO}$ in the NIR region. The spectrum of $\mathrm{GR}-\mathrm{ZnO}-\mathrm{CoPc}$ (Figure $7 \mathrm{~b}$ ) revealed the absorption bands analogue to $\mathrm{GR}$ and $\mathrm{ZnO}$ at 275 and $370 \mathrm{~nm}$, respectively. The absorption owing to CoPc was not observed in $\mathrm{GR}-\mathrm{ZnO}-\mathrm{CoPc}$, which could be because of minute concentration of CoPc. However, a slight shifting in the bands related to GR and $\mathrm{ZnO}$ has been found in GR$\mathrm{ZnO}-\mathrm{CoPc}$ compared to GR-ZnO. It could be due to variation in the electronic absorption of $\mathrm{GR}-\mathrm{ZnO}$ caused by the manifestation of $\mathrm{CoPc}$ in $\mathrm{GR}-\mathrm{ZnO}-\mathrm{CoPc}$. However, $\mathrm{GR}-\mathrm{ZnO}-\mathrm{CoPc}$ revealed its predominant activity under exposure to NIR radiations by exhibiting substantial absorption in the NIR region.

In consideration of their substantial absorption in the NIR region, PTE of GR- $\mathrm{ZnO}$ and $\mathrm{GR}-\mathrm{ZnO}-\mathrm{CoPc}$ was measured by irradiating their aqueous dispersion to $980 \mathrm{~nm}$ laser and compared with that of water, GR nanosheets, and $\mathrm{ZnO}$ particles. Figure 8 illustrates the PTE of the samples determined under identical experimental conditions at their concentration of $1 \mathrm{~g} / \mathrm{mL}$. The temperature recorded during measurement of PTE is summarized in Table 1. By continuous illumination to laser for $7 \mathrm{~min}$, temperature of water increased from 22.8 to $31.1{ }^{\circ} \mathrm{C}$ with total difference $(\Delta T)$ of $8.3{ }^{\circ} \mathrm{C}$. Whereas $\Delta T$ found for $\mathrm{ZnO}$ particles was $23.7^{\circ} \mathrm{C}$, that is $22.8-46.5{ }^{\circ} \mathrm{C}$. The elevation in temperature measured for GR nanosheets was from 22.6 to $51.3^{\circ} \mathrm{C}$, with an estimated $\Delta T$ of $28.7^{\circ} \mathrm{C}$. Interestingly, by conjugation of GR nanosheets and $\mathrm{ZnO}$ particles, their PTE was significantly enhanced in GR$\mathrm{ZnO}$ compared to their individual values. In detail, $\mathrm{GR}-\mathrm{ZnO}$ exhibited $\Delta T$ of $36.4{ }^{\circ} \mathrm{C}$ with initial and final temperatures of 22.9 and $59.3{ }^{\circ} \mathrm{C}$, respectively. The PTE of GR nanosheets and $\mathrm{ZnO}$ particles was enhanced by 7.7 and $12.7{ }^{\circ} \mathrm{C}$, respectively, after their conjugation in $\mathrm{GR}-\mathrm{ZnO}$. The improvement found in the PTE of GR nanosheets and $\mathrm{ZnO}$ particles after their conjugation was accounted for by the heterojunctioned structure formed between them in GR- $\mathrm{ZnO}$. In case of $\mathrm{GR}-\mathrm{ZnO}-\mathrm{CoPc}$, an increase of $44.9^{\circ} \mathrm{C}$ was recognized from 22.8 to $67.7^{\circ} \mathrm{C}$, so PTE of GR- $\mathrm{ZnO}$ was further improved by sensitizing with CoPc. The advancement of $8.5^{\circ} \mathrm{C}$ found in $\mathrm{GR}-\mathrm{ZnO}-\mathrm{CoPc}$ compared to $\mathrm{GR}-\mathrm{ZnO}$ was accounted for by the presence of CoPc. Overall, a systematical improvement in the PTE of the GR nanosheets and $\mathrm{ZnO}$ particles is achieved by their perfect combination and subsequent sensitization with CoPc. The advancement in the PTE of GR- $\mathrm{ZnO}$ and GR$\mathrm{ZnO}-\mathrm{CoPc}$ was precisely estimated through estimation of their photothermal conversion efficiency $(\eta)$ by means of Roper's method using eq $1^{30-33}$ 

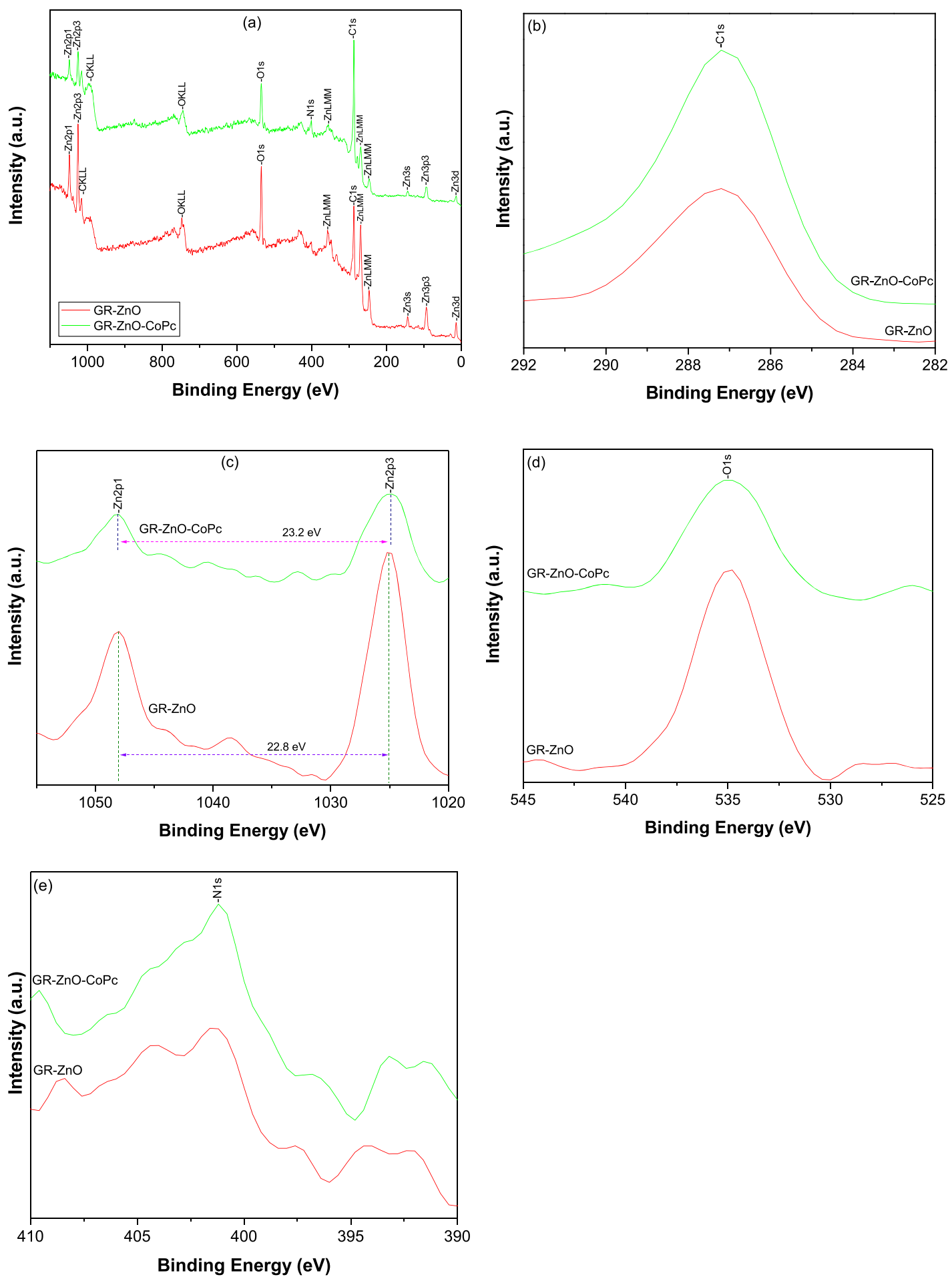

Figure 6. (a) XPS survey spectra of GR-ZnO and GR-ZnO-CoPc and high resolution spectra of (b) C 1s, (c) Zn 2p, (d) O 1s, and (e) N 1s.

$$
\eta=\frac{h S\left(T_{\max }-T_{\text {surr }}\right)-Q_{\text {dis }}}{I\left(1-10^{-A_{980}}\right)}
$$

heat dissipated owing to absorption of light by solvent and container.

To evaluate the value of $h S$, a dimensionless driving force of where $\eta$ is the photothermal efficiency, $h$ is heat-transfer coefficient, and $S$ is the surface area of the sample container. $T_{\max }$ is the maximum temperature attained by the sample, and $T_{\text {surr }}$ is the surrounding temperature. The values of these parameters are provided in Table 2. $I$ is power of the laser source $(2000 \mathrm{~mW})$, and $A_{980}$ is absorbance of aqueous dispersion of samples at excitation of $980 \mathrm{~nm}$. $Q_{\text {dis }}$ is rate of temperature, $\theta$, was introduced and scaled using the maximum system temperature, $T_{\max }$ and the surrounding temperature, $T_{\text {surr }}$

$$
\theta=\frac{T-T_{\text {surr }}}{T_{\max }-T_{\text {surr }}}
$$




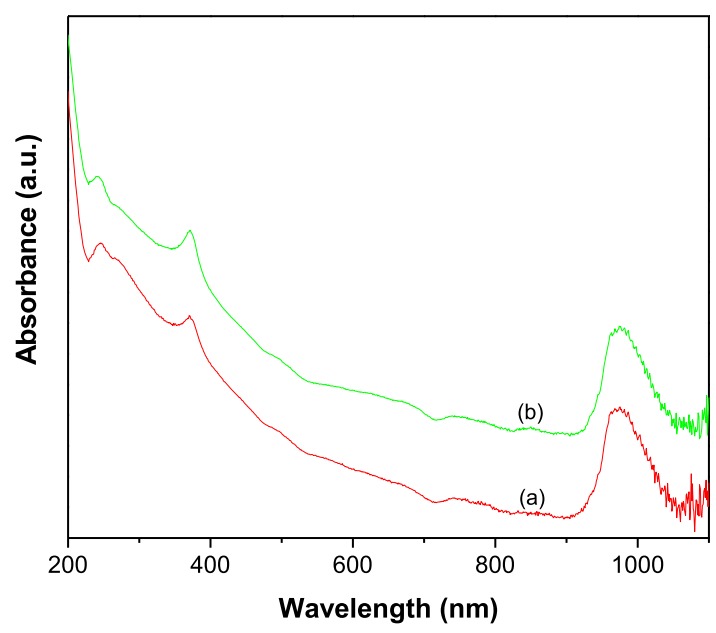

Figure 7. UV-vis-NIR spectra of (a) GR- $\mathrm{ZnO}$ and (b) GR-ZnOCoPc.

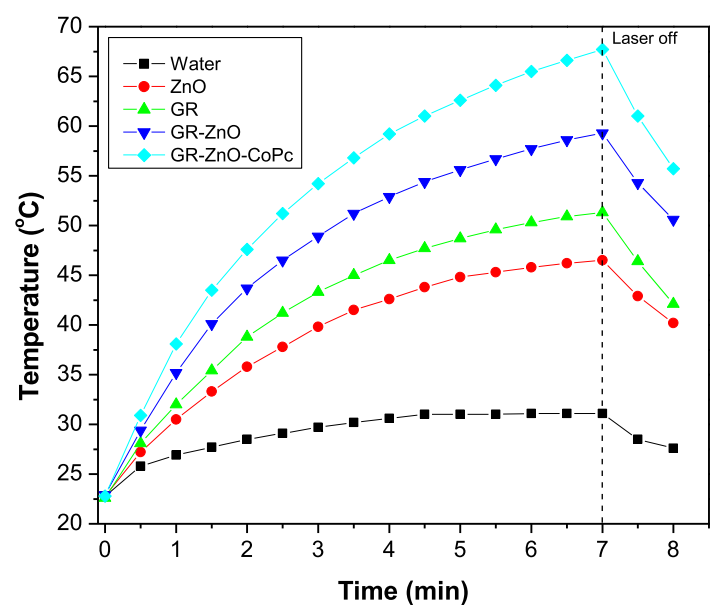

Figure 8. Rise in temperature for aqueous dispersions of samples as a function of time of illumination under exposure to $980 \mathrm{~nm}$ laser.

and the sample system time constant, $\tau_{\mathrm{s}}$, was determined by eq 3

$$
t=-\tau_{\mathrm{s}} \ln (\theta)
$$

The value of $\tau_{\text {s }}$ was estimated by Figures S3 and S4, and it was found to be 347 and $346 \mathrm{~s}$ for GR- $\mathrm{ZnO}$ and GR-ZnO$\mathrm{CoPc}$, respectively. Using the value of $\tau_{\mathrm{s}}$, the unknown parameter, $h S$ was calculated by eq 4 .
Table 2. Properties Utilized in the Calculation of Photothermal Conversion Efficiency

\begin{tabular}{lccccc}
\multicolumn{1}{c}{ sample } & $T_{\max }$ & $T_{\text {surr }}$ & $T_{\max }-T_{\text {surr }}$ & & \\
GR-ZnO & $\left({ }^{\circ} \mathrm{C}\right)$ & $\left({ }^{\circ} \mathrm{C}\right)$ & $\left({ }^{\circ} \mathrm{C}\right)$ & $A_{980}$ & $\eta(\%)$ \\
GR-ZnO-CoPc & 59.3 & 22.9 & 36.4 & 0.817 & 25 \\
& 67.7 & 22.8 & 44.9 & 0.821 & 32 \\
\hline
\end{tabular}

$$
h S=\frac{m_{\mathrm{D}} C_{\mathrm{D}}}{\tau_{\mathrm{s}}}
$$

where $m_{\mathrm{D}}(1.01 \mathrm{~g})$ is mass of deionized (DI) water, and $C_{\mathrm{D}}$ is its heat capacity. The value of $Q_{\text {dis }}$ was measured separately using a quartz cuvette containing only DI water without any sample, and it was found to be $25.9 \mathrm{~mW}$.

The photothermal conversion efficiency $(\eta)$ calculated for $\mathrm{GR}-\mathrm{ZnO}$ was found to be $25 \%$. This value of $\eta$ estimated for $\mathrm{GR}-\mathrm{ZnO}$ containing rice grain-shaped $\mathrm{ZnO}$ microparticles was found to be lower than the value determined for $\mathrm{GR}-\mathrm{ZnO}$ having trapezoid-shaped $\mathrm{ZnO}$ nanoparticles (49\%). ${ }^{14}$ Therefore, photothermal conversion efficiency is controlled by morphology of $\mathrm{ZnO}$ particles, and the value of $\eta$ can be tuned by varying the morphology of $\mathrm{ZnO}$ particles.

The photothermal conversion efficiency of GR- $\mathrm{ZnO}$ was improved after sensitizing with CoPc. Hence, the value of $\eta$ estimated for GR- $\mathrm{ZnO}-\mathrm{CoPc}$ was $32 \%$, which is $7 \%$ higher than the efficiency of GR-ZnO. It shows that combination of $\mathrm{CoPc}$ with GR-ZnO can increase its absorbing aptitude to NIR radiations and result in enhancement of photothermal conversion efficiency. Therefore, sensitizing with CoPc could be an ideal modality to improve PTE of GR-ZnO. However, the photothermal conversion efficiency determined for both $\mathrm{GR}-\mathrm{ZnO}$ and $\mathrm{GR}-\mathrm{ZnO}-\mathrm{CoPc}$ were comparatively greater than the value estimated for well-known photothermal agents, viz., $\mathrm{Au}$ nanoshells (18\%), ${ }^{34} \mathrm{Au}$ nanorods $(22 \%),{ }^{35}$ and $\mathrm{Cu}_{2-x} \mathrm{Se}$ nanoparticles (22\%). ${ }^{36}$ Generally, the temperature forbearance of cancer cells is about $50{ }^{\circ} \mathrm{C},{ }^{37,38}$ whereas the maximum temperature attained with $\mathrm{GR}-\mathrm{ZnO}$ and GR$\mathrm{ZnO}-\mathrm{CoPc}$ during the measurement of their PTE was 59.3 and $67.7^{\circ} \mathrm{C}$, respectively. The temperature attained by GR$\mathrm{ZnO}$ and $\mathrm{GR}-\mathrm{ZnO}-\mathrm{CoPc}$ is beyond the survival temperature of cancer cells. Hence, both $\mathrm{GR}-\mathrm{ZnO}$ and $\mathrm{GR}-\mathrm{ZnO}-\mathrm{CoPc}$ would be able to generate sufficient heat needed to ablate cancer cells.

To analyze the stability of GR- $\mathrm{ZnO}-\mathrm{CoPc}$, it was applied in five cycles of PTE measurement and the PTE was almost constant in all five cycles (Figure S5). In addition, XRD of $\mathrm{GR}-\mathrm{ZnO}-\mathrm{CoPc}$ recorded after employing it in five cycles could not show any considerable modification compared to the unused $\mathrm{GR}-\mathrm{ZnO}-\mathrm{CoPc}$ (Figure S6). Hence, GR- $\mathrm{ZnO}-$

Table 1. Temperature of Samples Recorded during Measurement of PTE

\begin{tabular}{lccccc}
\multicolumn{1}{c}{ sample } & $\begin{array}{c}\text { laser system } \\
(\mathrm{nm})\end{array}$ & $\begin{array}{c}\text { concentration of aqueous } \\
\text { dispersion }(\mathrm{mg} / \mathrm{mL})\end{array}$ & $\begin{array}{c}\text { initial temperature prior to } \\
\text { irradiation with laser }\left({ }^{\circ} \mathrm{C}\right)\end{array}$ & $\begin{array}{c}\Delta T \\
\text { final temperature after irradiation } \\
\text { with laser for } 7 \text { min }\left({ }^{\circ} \mathrm{C}\right)\end{array}$ & $\begin{array}{c}\left(T_{\text {final }}-T_{\text {initial }}\right) \\
\left({ }^{\circ} \mathrm{C}\right)\end{array}$ \\
water & 980 & & 22.8 & 31.1 & 8.3 \\
$\mathrm{ZnO}$ & 980 & 1.00 & 22.8 & 46.5 & 23.7 \\
$\mathrm{GR}$ & 980 & 1.00 & 22.6 & 51.3 & 28.7 \\
$\mathrm{GR}-\mathrm{ZnO}$ & 980 & 1.00 & 22.9 & 59.3 & 67.7 \\
$\mathrm{GR}-\mathrm{ZnO}-\mathrm{CoPc}$ & 980 & 1.00 & 22.8 & 60.4 & 36.4 \\
$\mathrm{GR}-\mathrm{ZnO}-\mathrm{CoPc}$ & 980 & 0.50 & 22.9 & 51.3 & 34.9 \\
$\mathrm{GR}-\mathrm{ZnO}-\mathrm{CoPc}$ & 980 & 0.25 & 22.6 & 59.5 & 28.7 \\
$\mathrm{GR}-\mathrm{ZnO}-\mathrm{CoPc}$ & 808 & 1.00 & 22.7 &
\end{tabular}


CoPc possesses excellent stability against both photobleaching and structural rupture. Apart from this, the influence of concentration over PTE of GR- $\mathrm{ZnO}-\mathrm{CoPc}$ was identified by measuring at additional lower concentrations of 0.5 and 0.25 $\mathrm{g} / \mathrm{mL}$ and it was recognized that the PTE of GR- $\mathrm{ZnO}-\mathrm{CoPc}$ was directly related to its concentration (Figure S7). The calculated values of $\Delta T$ for $\mathrm{GR}-\mathrm{ZnO}-\mathrm{CoPc}$ at its concentrations of $0.25,0.5$, and $1 \mathrm{~g} / \mathrm{mL}$ were $28.7,37.5$, and $44.9^{\circ} \mathrm{C}$, respectively. In detail, $\Delta T$ estimated between 0.25 and $0.5 \mathrm{~g} / \mathrm{mL}$ was $9{ }^{\circ} \mathrm{C}$ and it was $7.4{ }^{\circ} \mathrm{C}$ between 0.5 and $1 \mathrm{~g} / \mathrm{mL}$. Furthermore, the impact of the NIR laser source over PTE of $\mathrm{GR}-\mathrm{ZnO}-\mathrm{CoPc}$ was revealed by replacing the $980 \mathrm{~nm}$ laser system with an $808 \mathrm{~nm}$ laser. It was found that PTE of GR$\mathrm{ZnO}-\mathrm{CoPc}$ was reduced under irradiation to $808 \mathrm{~nm}$ laser compared to $980 \mathrm{~nm}$ laser (Figure S8). The reduction that occurred in the PTE of GR- $\mathrm{ZnO}-\mathrm{CoPc}$ under irradiation to $808 \mathrm{~nm}$ laser could be explained by its UV-vis-NIR spectrum shown in Figure $7 \mathrm{~b}$ as it possesses low absorbance at $808 \mathrm{~nm}$ compared to $980 \mathrm{~nm}$, which reduced the PTE with $808 \mathrm{~nm}$ laser.

\section{CONCLUSIONS}

In summary, a promising photothermal agent, GR- $\mathrm{ZnO}-$ $\mathrm{CoPc}$ was designed by deposition of rice grain-shaped $\mathrm{ZnO}$ particles over GR nanosheets and successive sensitization with CoPc. The PTE of GR-ZnO was considerably improved by its sensitization with CoPc. The hybrid structure formed between GR nanosheets, $\mathrm{ZnO}$ particles, and $\mathrm{CoPc}$ transpired an exceptional PTE of GR-ZnO-CoPc. The sequential enhancement in the PTE of GR nanosheets was successfully attained by immobilization of $\mathrm{ZnO}$ over their surfaces and sensitization of CoPc. The value of the photothermal conversion efficiency estimated for $\mathrm{GR}-\mathrm{ZnO}-\mathrm{CoPc}$ was experimentally verified to show its effectiveness as a promising NIR active photothermal agent. The $\mathrm{GR}-\mathrm{ZnO}-\mathrm{CoPc}$ demonstrated higher photothermal conversion efficiency than well-known gold- and copper-based photothermal agents. Apart from its excellent PTE, GR-ZnO-CoPc demonstrated strong resistance against photobleaching and structural rupture. The PTE of GR$\mathrm{ZnO}-\mathrm{CoPc}$ was directly related to its concentration, and it was reduced by replacement of $980 \mathrm{~nm}$ laser system with 808 $\mathrm{nm}$ laser. The temperature attained by $\mathrm{GR}-\mathrm{ZnO}-\mathrm{CoPc}$ during measurement of PTE was absolutely excessive than survival temperature level of cancer cells. Therefore, on account of its excellence, GR- $\mathrm{ZnO}-\mathrm{CoPc}$ could be classified as a brilliant photothermal agent to apply in future PTT.

\section{EXPERIMENTAL SECTION}

4.1. Materials. The chemicals employed in the experiments were received from Sigma-Aldrich and were used without any further purification. For preparation of aqueous solutions, ultrapure water generated by Milli-Q Plus system (Millipore) was used.

4.2. Preparation of $\mathrm{GR}-\mathrm{ZnO}$. The $\mathrm{GR}-\mathrm{ZnO}$ was prepared according to ref 25 , in which GR oxide (GO) (40 $\mathrm{mg}$ ) prepared by the Hummers and Offeman method with few variations $^{39,40}$ was dispersed in DI water $(25 \mathrm{~mL})$ by sonication for $5 \mathrm{~min}$. Then, $20 \mathrm{~mL}$ aqueous solution of $\mathrm{ZnCl}_{2}(0.01 \mathrm{~mol})$ was added, and the reaction mixture was stirred for $15 \mathrm{~min}$ under ambient conditions. Subsequently, 2 $\mathrm{mL}$ of hydrazine hydrate $(2 \mathrm{~mL})$ was slowly added, and the reaction was proceeded for $1 \mathrm{~h}$ at room temperature. The resultant $\mathrm{GR}-\mathrm{ZnO}$ was obtained by centrifugation and purifying by sequential washings with $\mathrm{DI}$ water.

4.3. Preparation of GR-ZnO-CoPc. GR-ZnO (20 mg) was dispersed by sonication in $25 \mathrm{~mL}$ of DI water, and a solution of $2 \mathrm{mg}$ of $\mathrm{CoPc}$ in $5 \mathrm{~mL}$ dimethyl sulfoxide was gradually added. The resultant mixture was stirred for $2 \mathrm{~h}$ at room temperature, and thus formed $\mathrm{GR}-\mathrm{ZnO}-\mathrm{CoPc}$ was extracted by centrifugation and subsequently washed with DI water followed by its drying in vacuum.

4.4. Preparation of ZnO Particles and GR Nanosheets. For control experiments, $\mathrm{ZnO}$ particles and GR nanosheets were prepared; among these, the $\mathrm{ZnO}$ particles were synthesized by the method referred for GR- $\mathrm{ZnO}$ without using GO, and the GR nanosheets were produced by the reduction of $\mathrm{GO} .^{41}$

4.5. Photothermal Effect. PTE of the samples was estimated by 980 and $808 \mathrm{~nm}$ NIR lasers (Armlaser Inc. USA) having output power of $2 \mathrm{~W} / \mathrm{cm}^{2}$. For all samples, $1 \mathrm{~mL}$ aqueous dispersion in a quartz cuvette was irradiated with NIR laser. The resulting elevation in temperature facilitated by irradiation was recorded with Hanna precision digital thermometer (model: HI93510) carrying the thermocouple immersed in sample.

4.6. Characterization. To acquire FESEM images, a JEOL JXA-8900 microscope was used, and for TEM images and EDS, a JEOL 2010 microscope was utilized. To get XPS and XRD patterns, a PerkinElmer PHI 5600 ci X-ray photoelectron spectrometer and Scintag X-ray diffractometer (PAD X) fitted with $\mathrm{Cu} \mathrm{K} \alpha$ photon source $(45 \mathrm{kV}, 40 \mathrm{~mA})$, respectively, were employed. The UV-vis-NIR electronic absorption and ATR-IR spectra were perceived by a Varian Cary 50 Bio spectrophotometer and Smiths ChemID diamond ATR spectrometer, respectively.

\section{ASSOCIATED CONTENT}

\section{Supporting Information}

The Supporting Information is available free of charge on the ACS Publications website at DOI: 10.1021/acsomega.8b03222.

EDS of GR- $\mathrm{ZnO}$ and $\mathrm{GR}-\mathrm{ZnO}-\mathrm{CoPc}$; temperature variation found for aqueous dispersion of $\mathrm{GR}-\mathrm{ZnO}$ and $\mathrm{GR}-\mathrm{ZnO}-\mathrm{CoPc}$; the plot of time from cooling period versus negative natural logarithm of driving force temperature obtained for $\mathrm{GR}-\mathrm{ZnO}$ and $\mathrm{GR}-\mathrm{ZnO}-$ $\mathrm{CoPc}$; temperature variation measured for the aqueous dispersion of $\mathrm{GR}-\mathrm{ZnO}-\mathrm{CoPc}$ for five cycles, $\mathrm{XRD}$ of $\mathrm{GR}-\mathrm{ZnO}-\mathrm{CoPc}$ recorded before and after using in five successive cycles of PTE measurement, PTE of GR$\mathrm{ZnO}-\mathrm{CoPc}$ measured at different concentrations, PTE of $\mathrm{GR}-\mathrm{ZnO}-\mathrm{CoPc}$ measured under illumination of 980 and $808 \mathrm{~nm}$ laser systems (PDF)

\section{AUTHOR INFORMATION}

\section{Corresponding Author}

*E-mail: aroki@pvamu.edu (A.O.).

ORCID $\odot$

Gururaj M. Neelgund: 0000-0003-1256-7058

Notes

The authors declare no competing financial interest. 


\section{ACKNOWLEDGMENTS}

The authors acknowledge the support from NIH-NIGMS grant 1SC3GM121229-01, the department grant L0002 from Welch Foundation, Texas, United States, and PVAMU Faculty Research Development Grant.

\section{REFERENCES}

(1) Lim, J. H.; Kim, D. E.; Kim, E.-J.; Ahrberg, C. D.; Chung, B. G. Functional graphene oxide-based nanosheets for photothermal therapy. Macromol. Res. 2018, 26, 557-565.

(2) Pan, J.; Yang, Y.; Fang, W.; Liu, W.; Le, K.; Xu, D.; Li, X. Fluorescent phthalocyanine-graphene conjugate with enhanced NIR absorbance for imaging and multi-modality therapy. ACS Appl. Nano Mater. 2018, 1, 2785-2795.

(3) Vankayala, R.; Hwang, K. C. Near-infrared-light-activatable nanomaterial-mediated phototheranostic nanomedicines: An emerging paradigm for cancer treatment. Adv. Mater. 2018, 30, 17063201706347.

(4) Ghosal, K.; Sarkar, K. Biomedical applications of graphene nanomaterials and beyond. ACS Biomater. Sci. Eng. 2018, 4, 26532703.

(5) Neelgund, G. M.; Oki, A. R. Influence of carbon nanotubes and graphene nanosheets on photothermal effect of hydroxyapatite. $J$. Colloid Interface Sci. 2016, 484, 135-145.

(6) Novoselov, K. S.; Geim, A. K.; Morozov, S. V.; Jiang, D.; Zhang, Y.; Dubonos, S. V.; Grigorieva, I. V.; Firsov, A. A. Electric field effect in atomically thin carbon films. Science 2004, 306, 666-669.

(7) Lu, Y.-H.; Zhou, M.; Zhang, C.; Feng, Y.-P. Metal-embedded graphene: A possible catalyst with high activity. J. Phys. Chem. C 2009, 113, 20156-20160.

(8) Wang, B.; Chang, Y.-h.; Zhi, L.-j. High yield production of graphene and its improved property in detecting heavy metal ions. New Carbon Mater. 2011, 26, 31-35.

(9) Zhao, X.; Hayner, C. M.; Kung, M. C.; Kung, H. H. Flexible holey graphene paper electrodes with enhanced rate capability for energy storage applications. ACS Nano 2011, 5, 8739-8749.

(10) Parlak, O.; Tiwari, A.; Turner, A. P. F.; Tiwari, A. Templatedirected hierarchical self-assembly of graphene based hybrid structure for electrochemical biosensing. Biosens. Bioelectron. 2013, 49, 53-62.

(11) Zhang, M.; Wu, F.; Wang, W.; Shen, J.; Zhou, N.; Wu, C. Multifunctional nanocomposites for targeted, photothermal, and chemotherapy. Chem. Mater. 2018, DOI: 10.1021/acs.chemmater.8b00934, (In press)

(12) Neelgund, G. M.; Oki, A. Graphene-coupled ZnO: A robust NIR-induced catalyst for rapid photo-oxidation of cyanide. ACS Omega 2017, 2, 9095-9102.

(13) Bano, N.; Hussain, I.; Sawaf, S.; Alshammari, A.; Saleemi, F. Enhancement of external quantum efficiency and quality of heterojunction white LEDs by varying the size of $\mathrm{ZnO}$ nanorods. Nanotechnology 2017, 28, 245203-245209.

(14) Neelgund, G. M.; Oki, A. Photothermal effect: an important aspect for the enhancement of photocatalytic activity under illumination by NIR radiation. Mater. Chem. Front. 2018, 2, 64-75.

(15) Trino, L. D.; Albano, L. G. S.; Bronze-Uhle, E. S.; George, A.; Mathew, M. T.; Lisboa-Filho, P. N. Physicochemical, osteogenic and corrosion properties of bio-functionalized $\mathrm{ZnO}$ thin films: Potential material for biomedical applications. Ceram. Int. 2018, 44, 2100421014.

(16) Sandhya, P. K.; Jose, J.; Sreekala, M. S.; Padmanabhan, M.; Kalarikkal, N.; Thomas, S. Reduced graphene oxide and $\mathrm{ZnO}$ decorated graphene for biomedical applications. Ceram. Int. 2018, 44, 15092-15098.

(17) Kang, J.-S.; Ham, A.-R.; Kang, J.-G.; Leung, K. T. White and tunable emission from and rhodamine $\mathrm{B}$ detection by modified zinc oxide nanowalls. Langmuir 2018, 34, 9774-9780.

(18) Peng, J.; Zhao, L.; Zhu, X.; Sun, Y.; Feng, W.; Gao, Y.; Wang, L.; Li, F. Hollow silica nanoparticles loaded with hydrophobic phthalocyanine for near-infrared photodynamic and photothermal combination therapy. Biomaterials 2013, 34, 7905-7912.

(19) Lim, C.-K.; Shin, J.; Lee, Y.-D.; Kim, J.; Oh, K. S.; Yuk, S. H.; Jeong, S. Y.; Kwon, I. C.; Kim, S. Phthalocyanine-aggregated polymeric nanoparticles as tumor-homing near-infrared absorbers for photothermal therapy of cancer. Theranostics 2012, 2, 871-879.

(20) Jia, Q.; Ge, J.; Liu, W.; Zheng, X.; Wang, M.; Zhang, H.; Wang, P. Biocompatible Iron Phthalocyanine-Albumin Assemblies as Photoacoustic and Thermal Theranostics in Living Mice. ACS Appl. Mater. Interfaces 2017, 9, 21124-21132.

(21) Li, X.; Peng, X.-H.; Zheng, B.-D.; Tang, J.; Zhao, Y.; Zheng, B.Y.; Ke, M.-R.; Huang, J.-D. New application of phthalocyanine molecules: from photodynamic therapy to photothermal therapy by means of structural regulation rather than formation of aggregates. Chem. Sci. 2018, 9, 2098-2104.

(22) Taratula, O.; Taratula, O.; Patel, M.; Schumann, C.; Naleway, M.; He, H.; Pang, A. Phthalocyanine-loaded graphene nanoplatform for imaging-guided combinatorial phototherapy. Int. J. Nanomed. 2015, 10, 2347-2362.

(23) Soliman, H. S.; El-Barry, A. M. A.; Khosifan, N. M.; El Nahass, M. M. Structural and electrical properties of thermally evaporated cobalt phthalocyanine ( $\mathrm{CoPc}$ ) thin films. Eur. Phys. J.: Appl. Phys. 2007, 37, 1-9.

(24) Ogbodu, R. O.; Nyokong, T. The effect of ascorbic acid on the photophysical properties and photodynamic therapy activities of zinc phthalocyanine-single walled carbon nanotube conjugate on MCF-7 cancer cells. Spectrochim. Acta, Part A 2015, 151, 174-183.

(25) Neelgund, G. M.; Oki, A.; Luo, Z. $\mathrm{ZnO}$ and cobalt phthalocyanine hybridized graphene: Efficient photocatalysts for degradation of rhodamine B. J. Colloid Interface Sci. 2014, 430, 257-264.

(26) Gharagozlou, M.; Naghibi, S. Sensitization of $\mathrm{ZnO}$ nanoparticles by metal-free phthalocyanine. J. Lumin. 2018, 196, 64-68.

(27) Luo, Q.; Yang, X.; Zhao, X.; Wang, D.; Yin, R.; Li, X.; An, J. Facile preparation of well-dispersed $\mathrm{ZnO} /$ cyclized polyacrylonitrile nanocomposites with highly enhanced visible-light photocatalytic activity. Appl. Catal., B 2017, 204, 304-315.

(28) Tayyebi, A.; Soltani, T.; Lee, B.-K.; Outokesh, M.; Tayebi, M. Novel visible light photocatalytic and photoelectrochemical (PEC) activity of carbon-doped zinc oxide/reduced graphene oxide: supercritical methanol synthesis with enhanced photocorrosion suppression. J. Alloys Compd. 2017, 723, 1001-1010.

(29) Khai, T. V.; Thu, L. V.; Ha, L. T. T.; Thanh, V. M.; Lam, T. D. Structural, optical and gas sensing properties of vertically well-aligned $\mathrm{ZnO}$ nanowires grown on graphene/Si substrate by thermal evaporation method. Mater. Charact. 2018, 141, 296-317.

(30) Keith Roper, D.; Ahn, W.; Hoepfner, M. Microscale heat transfer transduced by surface plasmon resonant gold nanoparticles. $J$. Phys. Chem. C 2007, 111, 3636-3641.

(31) Neelgund, G. M.; Oki, A. Advancement in photothermal effect of carbon nanotubes by grafting of poly(amidoamine) and deposition of CdS nanocrystallites. Ind. Eng. Chem. Res. 2018, 57, 7826-7833.

(32) Neelgund, G. M.; Oki, A. Photothermal effect of Ag nanoparticles deposited over poly(amidoamine) grafted carbon nanotubes. J. Photochem. Photobiol., A 2018, 364, 309-315.

(33) Shi Kam, N. W.; O'Connell, M.; Wisdom, A.; Dai, H. Carbon nanotubes as multifunctional biological transporters and nearinfrared agents for selective cancer cell destruction. Proc. Natl. Acad. Sci. U.S.A. 2005, 102, 11600-11605.

(34) Huang, P.; Lin, J.; Li, W.; Rong, P.; Wang, Z.; Wang, S.; Wang, X.; Sun, X.; Aronova, M.; Niu, G.; Leapman, R. D.; Nie, Z.; Chen, X. Biodegradable gold nanovesicles with an ultrastrong plasmonic coupling effect for photoacoustic imaging and photothermal therapy. Angew. Chem., Int. Ed. 2013, 52, 13958-13964.

(35) Hessel, C. M.; Pattani, V. P.; Rasch, M.; Panthani, M. G.; Koo, B.; Tunnell, J. W.; Korgel, B. A. Copper selenide nanocrystals for photothermal therapy. Nano Lett. 2011, 11, 2560-2566. 
(36) Pattani, V. P.; Tunnell, J. W. Nanoparticle-mediated photothermal therapy: a comparative study of heating for different particle types. Lasers Surg. Med. 2012, 44, 675-684.

(37) Ju, E.; Dong, K.; Liu, Z.; Pu, F.; Ren, J.; Qu, X. Tumor microenvironment activated photothermal strategy for precisely controlled ablation of solid tumors upon NIR irradiation. Adv. Funct. Mater. 2015, 25, 1574-1580.

(38) Yoo, D.; Jeong, H.; Noh, S.-H.; Lee, J.-H.; Cheon, J. Magnetically triggered dual functional nanoparticles for resistancefree apoptotic hyperthermia. Angew. Chem., Int. Ed. 2013, 52, 1304713051 .

(39) Hummers, W. S.; Offeman, R. E. Preparation of graphitic oxide. J. Am. Chem. Soc. 1958, 80, 1339.

(40) Neelgund, G. M.; Bliznyuk, V. N.; Oki, A. Photocatalytic activity and NIR laser response of polyaniline conjugated graphene nanocomposite prepared by a novel acid-less method. Appl. Catal., B 2016, 187, 357-366.

(41) Neelgund, G. M.; Oki, A.; Luo, Z. In situ deposition of hydroxyapatite on graphene nanosheets. Mater. Res. Bull. 2013, 48, 175-179. 